\title{
Litter Decomposition Rate of Avicennia marina and Rhizophora apiculata in Pulau Dua Nature Reserve, Banten
}

Febriana Siska ${ }^{1}$, Sulistijorini ${ }^{2 *}$, Cecep Kusmana ${ }^{3}$

\author{
${ }^{1}$ Plant Biology Graduate Program, Bogor Agricultural University, Bogor, Indonesia \\ ${ }^{2}$ Departement of Biology, Faculty of Mathematics and Natural Sciences, Bogor Agricultural University, Bogor, Indonesia \\ ${ }^{3}$ Departement of Silviculture, Faculty of Forestry, Bogor Agricultural University, Bogor, Indonesia
}

\section{ABSTRACT}

Litter decomposition rate is useful method to determine forest fertility level. The aims of this study were to measure decomposition rate of litters from Avicennia marina and Rhizophora apiculata forest in Pulau Dua Banten, and analyze their nutrient content during the process. Litter was obtained using a trap system and the decomposition was done on the field. Our results showed that the decomposition rate of $A$. marina $(\mathrm{k}=0.83)$ was higher than that of $R$. apiculata $(\mathrm{k}=0.41)$. The $\mathrm{k}$ value was an average of $\mathrm{C} / \mathrm{N}$ ratio further whom showed that litter decomposition rate in Pulau Dua Nature Reserve was relatively slow.

Keywords: Avicennia marina, leaf anatomical structure, litter decomposition, Pulau Dua, Rhizophora apiculata, salinity

\section{INTRODUCTION}

Mangrove leaf litter has a very important function for mangrove ecosystem, especially to maintain soil fertility. Soil fertility and plant growth are depending on the litter productivity and decomposition rate [1]. Decomposed litter contributes to the availability of organic matter in the forest soil as well as source of food for soil fauna. Accumulation of organic matter has a beneficial function to enrich the nutrient of the mangrove ecosystems as nursery grounds, spawning ground, and protection place for a variety of aquatic biota [2].

The stable decomposition process has a role to keep the nutrients supply to the soil. If decomposition process is too slow, nutrient availability will decrease. In the other hand, rapid decomposition process can cause the nutrient lost during soil leaching and evaporation, affecting to the disruption of plant growth [3].

Controlling factors effecting the rate of litter decomposition are $\mathrm{pH}$, climate (temperature and humidity), the chemical composition of litter, and soil microorganisms [4]. $\mathrm{pH}$ affect the activity of cellulose enzymes produced by microorganisms such as fungi in the litter decomposition [5]. Temperature is a physical

*Corresponding author:

Sulistijorini

Department of Biology, Bogor Agricultural University

Jalan Raya Darmaga, Bogor 16680, Indonesia

E-mail: ssulistijorini@yahoo.com parameter that affects physiology properties microorganisms that live in the environment. The chemical composition from litter as organic carbon (C), nitrogen $(\mathrm{N})$, and phosphor $(\mathrm{P})$ to affect the speed of litter decomposition rates. According Aprianis (2011) [1], that the $\mathrm{C} /$ is an indicator to see decomposition rate of organic material. Phosphorus is one of the essential nutrients due compound will be absorbed by phytoplankton and get into the food chain [6].

Geographically, Pulau dua is located between $06^{\circ} 01^{\prime} \mathrm{SL}$ and $106^{\circ} 12^{\prime} \mathrm{EL}$. It is a lowland with total area of 30 ha. Vegetation type that grown in this island is mangrove community in which $60 \%$ dominated by A. marina, especially in the southern part of the island, while the eastern part is over-grown by $R$. apiculata [7]. Pulau Dua Nature Reserve is known as a habitat for many species of birds and a haven of migratory birds [8].

The mangrove ecosystem in Pulau Dua Nature Reserve has been degraded due to the expansion of aquaculture and accumulation of trash around the river. It was affects to the low density and uneven distribution of mangrove. The mangrove ecosystem has an important role to decomposition rate. Therefore, research on

How to cite:

Siska F, Sulistijorini, Kusmana C (2016) Litter decomposition rate of Avicennia marina and Rhizophora apiculata in Pulau Dua nature reserve, Banten. J. Trop. Life. Science 6 (2): 91 96. 
the decomposition rate of $A$. marina and $R$. apiculata litters in Pulau Dua Nature Reserve, Banten, was needed to be done.

This research is expected to basic data of management mangrove forest sustainable. In addition, this study can be used as additional information about decomposition rate of mangrove species that contributes to as the biggest contributor to the fertility of estuaries and coastal waters, so that stakeholders can optimize prioritized mangrove species to be planted in the area of Pulau Dua Nature Reserve Banten.

The aims of this study were to measure the rate of litter decomposition and nutrient content (organic $\mathrm{C}$, $\mathrm{N}$, and $\mathrm{P}$ ) produced during decomposition process on the A. marina and $R$. apiculata in the Pulau Dua Nature Reserve, Banten.

\section{MATERIALS AND METHODS}

\section{Time and place of research}

This study was conducted from August 2014 to May 2015 in Pulau Dua Nature Reserve Banten, on two forest community were $A$. marina and $R$. apiculata. Analysis of organic C, N, and P of leaf litter was carried out in the laboratory of Soil Research Institute Cimanggu, Bogor.

\section{Observation of litter decomposition rate}

Observation of litter decomposition rate was using litter bag method Ashton et al. (1999) [9], it was started with the collection of leaf litter for two weeks under the tree. Sample collection was carried out by putting 13 litter traps in each station. After two weeks, leaf litter was gathered and dried by oven with a temperature of $80^{\circ} \mathrm{C}$ (to constant weight). About $50 \mathrm{~g}$ of dried leaf litter from each station was analized for organic $\mathrm{C}, \mathrm{N}$, and $\mathrm{P}$. The rest of leaf litter was put in 36 litterbags ( size $30 \times 40 \mathrm{~cm}$ with mesh size $2 \mathrm{~mm}$ ), of 36 litterbags were filled by dried leaf litter (weight $35 \mathrm{~g}$ ), tied to the roots or trees to avoid drifting sea water. Every fifteen days 6 litterbags were taken from the second observation station [9]. Litter sample was dried in oven at $80^{\circ} \mathrm{C}$ to achieve a constant weight, and the nutrient content i.e. organic $\mathrm{C}, \mathrm{N}$, and $\mathrm{P}$ was analyzed. The measurement of environmental parameters such as temperature, salinity, $\mathrm{pH}$, and dissolved oxygen (DO) were performed in situ with 3 repetitions. The measurements of environmental parameters were done in the morning around 07.00-10.00 pm, at the same timing with litter bags collection.

\section{Measurement of leaf area}

About 30 healthy leaves and in the absence of holes from $A$. marina and $R$ apiculata trees were taken for the measurement of leaf area. Leaves were photographed using a camera and measured its area by using ImageJ software.

\section{Leaf anatomy}

Anatomical observation of leaf was done by using the frozen section technique: leaf preparate of $A$. marina and $R$. apiculata were made by slicing the leaf crosswise with a thickness of 20-30 $\mu \mathrm{m}$ using a freezing microtome. Sliced leaf was taken by using a pin and soaked in the petri dish containing chlorox, washed with water, and stained with safranin. After the staining, the sliced leaf was placed on the glass object, dropped by glycerin $30 \%$, and covered by a cover glass. Preparate was observed under a microscope and photographed using optilab. Parameters measured were the arrangement, shape, and thickness of the tissue.

\section{Data analysis}

Analysis of the data included the rate of litter decomposition, using Olson (1963) formula, 2 sample $t$ test, and regression. Litter decomposition rates estimated using the formula of Olson (1963) [10]:

$$
\mathrm{Xt}=\mathrm{Xo} \cdot \mathrm{e}^{-\mathrm{kt}}
$$

Xt : Dry weight of litter after observation period to - $t(\mathrm{~g})$

Xo : Weight of initial litter $(\mathrm{g})$

e : Natural of logaritma (2.72)

$\mathrm{k} \quad$ : Litter decomposition rate

$\mathrm{t}$ : Observation period (day)

\section{RESULTS AND DISCUSSION}

\section{The rate of decomposition}

The litter that fall to the forest ground will undergo the decomposition process. The weight of leaf litter decreased in each period of observations for 90 days. The percentage of the rest litter weight of $A$. marina and $R$. apiculata were significantly different $(\mathrm{P}=0.001)$. The rest litter weight of $A$. marina was lower (31.3\%) compared to $R$. apiculata (56.38\%) (Figure 1). Constants (k) of the decomposition rate of $A$. marina and $R$. apiculata litters were 0.83 and 0.41 , respectively. It was indicated that decomposition of $A$. marina leaf litter was faster than $R$. apiculata. Such condition was influenced by several factors, such as; morphology and anatomy of leaves, $\mathrm{N}$ element, substrate, physical and environmental factors. 


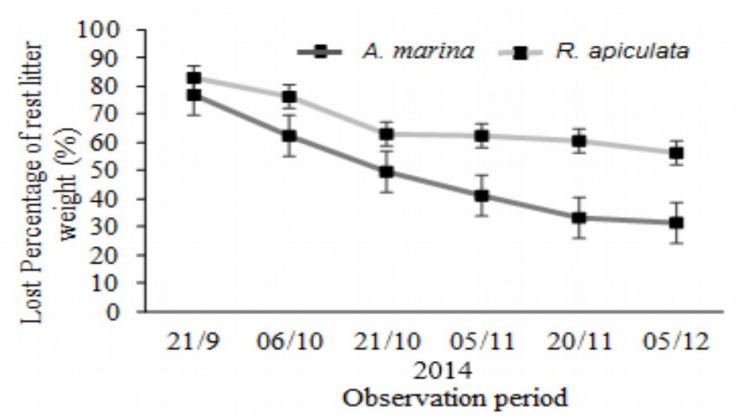

Figure 1. The average change $( \pm)$ standard deviation of the decomposition rate of $A$. marina and $R$. apiculata leaf litter during the observation period

Leaf of $A$. marina has a different morphology compared than $R$. apiculata, it showed by the value Specific Leaf Area (SLA). Leaf of $A$. marina has SLA is larger $\left(105.17 \mathrm{~cm}^{2} \cdot \mathrm{g}^{-1}\right)$ compared with $R$. apiculata $(66.07$ $\left.\mathrm{cm}^{2} \cdot \mathrm{g}^{-1}\right)$. Garnier et al. (2004) [11] stated that there is a positive relationship between the SLA with the rate of leaf litter decomposition. Large SLA tends to have faster decomposition rate [12].

Leaf litter of $A$. marina has the nitrogen content higher than $R$. apiculata (Table 2). Based on Choong et al. (1992) [13], decomposers like the litter that has a high nitrogen content. In addition, the high rate of $A$. marina leaf litter decomposition was caused by environmental substrates [14]. Substrate in $A$. marina community dominated by mud, while in $R$. apiculata community by muddy sand. It is supported by the study of Syamsurisal (2011) [15] that prove that in the muddy soil microbial decomposers are more common than in the muddy sand soil. Mud accumulates a lot of organic material as a potential food for the organisms [16].

The anatomy layer of $A$. marina leaf is thinner than $R$. apiculata leaf (Figure 2). A. marina has one layer epidermis, while $R$. apiculata has two layers epidermis. Decomposition rate was affected by the thickness of epidermis layers. Epidermis layer will protect the underneath tissue from the damage The thicker epidermis layer has a lower decomposition rate. Salt gland of A. marina is wider than $R$. apiculata. Wider salt glands will have more microorganisms because the humid condition that supports litter decomposition process. This is consistent with Chapman (1976) [17] which describes salt glands has a role to hold the tide inundation and give the humid condition to support the activity of soil microorganisms in the leaf litter decomposition.

Environmental conditions greatly affect do to process of litter decomposition. Temperature, salinity, humidity, DO, and $\mathrm{pH}$ observed in the Pulau Dua Nature Reserve were still in a good range value for the decomposition process. Regression results indicated the environmental condition factors have significant effect on the decomposition rate of $A$. marina leaf litter ( $\mathrm{P}=$ 0. 000), while the environmental condition factors did not have a significant effect on the decomposition rate of $R$. apiculata leaf litter $(\mathrm{P}=0.078)$ (Table 1$)$. Salinity value $(\mathrm{P}=0.041)$ and $\mathrm{DO}(\mathrm{P}=0.000)$ have a significant effect on the rate of leaf litter decomposition of $A$. marina, while the salinity factor $(\mathrm{P}=0.023)$ has a significant effect on the rate of leaf litter decomposition of $R$. apiculata.

Water salinity in $A$. marina community ranged of 25.33-27.87 psu, and the $R$. apiculata community ranged of 28.00- $29.67 \mathrm{psu}$. In both mangrove communities, the salinity of water was quite high. Yunasfi (2006) [18] reported that litter production at salinity 20-30 psu are less than salinity $<10,10-20$, and $>30$ psu. Dix and Webster (1995) [19] reported that the salinity of 20-30 psu found more worms than the salinity of less than 20 psu or higher than 30psu. It indicates that fastest decomposition rate can be reached at salinity 20-30 psu. Worms has a role to break down the litter in which faster fragmentation of litter will affect to the faster rate of litter decomposition.

DO value of two communities in Pulau Dua $\mathrm{Na}$ ture Reserve ranged between $5.60-8.20 \mathrm{ppm}$. The value of DO from this study was categoried quite high. The DO value need for macrobenthos ranges from 1.00 to $3.00 \mathrm{ppm}$ [20]. Tahir (2012) [21] explained that greater DO content in ecosystem will affect to the betttter macrobenthos life. Lee et al. (1978) [22] categorized water quality based on the DO content namely; not polluted (> $6.5 \mathrm{ppm})$. lightly polluted $(4.5-6.5 \mathrm{ppm})$. moderate polluted $(2.0-4.4 \mathrm{ppm})$, and heavily polluted $(<2.0 \mathrm{ppm})$. The value of $\mathrm{DO}$ in this $A$. marina community ranged between $5.70-8.20 \mathrm{ppm}$ and $R$. apiculata community ranged between $5.60-7.80 \mathrm{ppm}$, were categorized into lightly polluted and not polluted.

The releasing of nutrients from decaying organic matter is very important for the ecosystem. The nutrients will lost if the decomposing process is too fast due to the soil leaching and evaporation. Conversely, if the decomposing process is too slow, the plant growth will be disrupted because the lack of nutrient supplies [3]. In this study, nutrients matters i.e. $\mathrm{C}$ tended to decrease, $\mathrm{N}$ and $\mathrm{P}$ tended to increase (Table 2). This result has a similar case with Ulqodry (2008) [23] in which $\mathrm{C}$ content tended to decrease along with the decomposition period and litter size reduction. 
Table 1. Results of factors regression analysis including temperature, salinity, humidity, $\mathrm{DO}$ and $\mathrm{pH}$ on litter decomposition rate of $A$. marina and $R$. apiculata

\begin{tabular}{ccccc}
\hline Types & $R^{2}$ & adj $R^{2}$ & Regression equation & Regression ANOVA \\
\hline A. marina & 0.96 & 0.94 & $\mathrm{Y}=178-1.34 \mathrm{X}_{1}-3,74 \mathrm{X}_{2}-1.54 \mathrm{X}_{3}+16.2 \mathrm{X}_{4}+3.79 \mathrm{X}_{5}$ & $0.000<0.05$ \\
R. apiculata & 0.52 & 0.33 & $\mathrm{Y}=-911+6.75 \mathrm{X}_{1}+7.8 \mathrm{X}_{2}+7.45 \mathrm{X}_{3}+2.39 \mathrm{X}_{4}-9.19 \mathrm{X}_{5}$ & $0.078>0.05$ \\
\hline
\end{tabular}

Note:

${ }^{\mathrm{a}} \mathrm{Y}=$ Decomposition rate; $\mathrm{X}_{1}=$ temperature; $\mathrm{X}_{2}=$ salinity; $\mathrm{X}_{3}=$ humidity; $\mathrm{X}_{4}=\mathrm{DO} ; \mathrm{X}_{5}=\mathrm{pH}$

Table 2. The concentration of $\mathrm{C}, \mathrm{N}$, and P from leaf litter of $A$. marina and R. apiculata

\begin{tabular}{llllll}
\hline \multirow{2}{*}{ Forest Community } & $\begin{array}{c}\text { Observation period } \\
\text { Every (15 days) }\end{array}$ & Carbon (\%) & Nitrogen (\%) & C/N Ratio & Phosphor (ppm) \\
\cline { 3 - 6 } & $06 / 09 / 2014$ & 42.72 & 0.43 & 99.35 & 0.04 \\
& $21 / 09 / 2014$ & 41.49 & 0.65 & 63.83 & 0.05 \\
& $06 / 10 / 2014$ & 39.16 & 0.91 & 43.03 & 0.06 \\
A. marina & $21 / 10 / 2014$ & 35.66 & 0.96 & 37.15 & 0.07 \\
& $05 / 11 / 2014$ & 38.27 & 1.23 & 31.11 & 0.09 \\
& $20 / 11 / 2014$ & 36.00 & 1.19 & 30.25 & 0.08 \\
& $05 / 12 / 2014$ & 23.04 & 1.07 & 21.53 & 0.08 \\
\hline \multirow{5}{*}{ R. apiculata } & $06 / 09 / 2014$ & 51.87 & 0.24 & 216.13 & 0.02 \\
& $21 / 06 / 2014$ & 42.91 & 0.38 & 178.79 & 0.04 \\
& $06 / 10 / 2014$ & 39.03 & 0.48 & 81.31 & 0.04 \\
& $21 / 10 / 2014$ & 40.97 & 0.49 & 83.61 & 0.04 \\
& $05 / 11 / 2014$ & 34.01 & 0.58 & 58.64 & 0.04 \\
& $20 / 11 / 2014$ & 31.16 & 0.64 & 48.69 & 0.06 \\
$05 / 12 / 2014$ & 22.84 & 0.86 & 26.56 & 0.05 \\
\hline
\end{tabular}
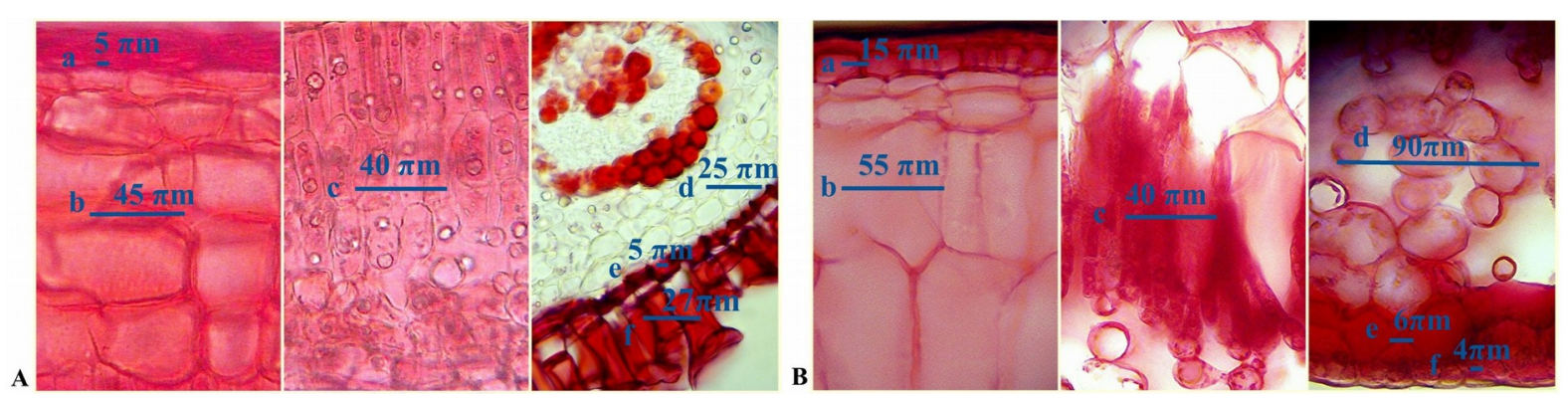

Figure 2. Cross section of $A$. marina leaf and $R$. apiculata (magnification $40 \times$ ). A. marina leaf: a. The upper epidermis; b. hypodermis; c. Palisade; d. Sponge; e. Lower epidermis; f. Salt glands; B. R. apiculata leaf: a. The upper epidermis; b. hypodermis; c. Palisade; d. Sponge; e. Lower epidermis; f. salt glands

The increasing of $\mathrm{N}$ content may be caused by the nitrogen-fixing bacteria role in the leaf litter [24]. Whereas the increase of the phosphor content according to Wijiyono (2009) [25] is due to the high decomposition rate that cause the release of phosphorus into the litter greater than to the environment.
$\mathrm{P}$ element content of the litter was lower than $\mathrm{N}$ because $\mathrm{P}$ is needed more compared to $\mathrm{N}$. The $\mathrm{P}$ elements make up about $2 / 5$ of the total microorganism ash. About 1/10 of $\mathrm{P}$ elements from $\mathrm{N}$ necessity are needed to arrange the cell. Total of phosphate levels in the water are classified into water with low fertility rate 
have a total phosphate ranging from $0-0,02 \mathrm{mg} / \mathrm{L}$, water with moderate fertility rate ranging from 0.021 $-0.05 \mathrm{mg} / \mathrm{L}$, and water with high fertility rate ranging from $0.05-0.1 \mathrm{mg} / \mathrm{L}$ [26]. Based on the classification above, $A$. marina belongs to the water with high fertility rate category, while $R$. apiculata belongs to the water with moderate fertility rate category.

Another factor that affecting the litter decomposition rate is the nutritional value of the leaves. The nutritional value can be analyzed from $\mathrm{C} / \mathrm{N}$ ratio [9]. $\mathrm{C} / \mathrm{N}$ ratio ranging between $25: 1$ and $30: 1$ is the optimum combination for rapid decomposition. [27]. If the $\mathrm{C} / \mathrm{N}$ ratio is too high, the microbes will lack of $\mathrm{N}$ supply for protein synthesis thus affecting to the slow decomposition process. $\mathrm{C} / \mathrm{N}$ ratio of $A$. marina leaf (21.53) was lower than $R$. apiculata leaf (26.56), which causes leaf decomposition process of A.marina was faster than $R$. apiculata. Low $\mathrm{C} / \mathrm{N}$ value showed high content of nitrogen and its indicated the rapid decomposition rate [7]. The value of $\mathrm{C} / \mathrm{N}$ ratio in pulau dua nature reserve, banten indicated that the litter decomposition rate is relatively slow.

\section{CONCLUSION}

The average of leaf litter decomposition rate $A$. marina faster (0.83) than the leaf litter $R$. apiculata (0.41), indicating that A. marina leaf litter contributes greatly to soil fertility forest mangroves in Pulau Dua Nature Reserve Banten. During the period of weathering litter $A$. marina and $R$. apiculata of $\mathrm{N}$ and $\mathrm{P}$ were removed more and more with the length of the litter weathering, contrary to the element C. The nutrients are released in succession $\mathrm{P}>\mathrm{N}>\mathrm{C}$.

\section{ACKNOWLEDGMENT}

\section{REFERENCES}

1. Aprianis Y (2011) Produksi dan laju dekomposisi serasah Acacia crassicarpaa. Cunn. PT. Arara Abadi. BPHPS Riau. 4 (1): 41-47.

2. Wibisana BT (2004) Produksi dan laju dekomposisi serasah mangrove di wilayah pesisir Kabupaten Berau Provinsi Kalimantan Timur. Skripsi. Bogor Agricultural University, Departemen Ilmu Kelautan.

3. Asri IP, Rachman S, Kabirun S (1990) Pengaruh penambahan biomassa algae terhadap penurunan $\mathrm{C}$ organik pada dekomposisi limbah tanaman nanas. Agrosains. 12(3): 269-279.

4. Saetre P (1998) Decomposition microbial community strusture and earthworm effects along a birch-spure soil gadient. Ecology. 79: 834-846.

5. Kulp K (1975) Carbohydrases in: Reed G, editor. Enzymes and Processing. New York (UK): Academic Press.

6. Hutagalung HP, Rozak A (1997) Metode Analisis Air Laut, Sedimen dan Biota. Buku 2. Jakarta: Pusat Penelitian dan Pengembangan Oseanologi LIPI.

7. Rusila NY, Andalusi N, Umar, et al. (1996) Penghitungan burung air di Pulau Dua dan Pulau Pamujan Besar Teluk Banten. Jawa Barat, Indonesia Database PHPA/ Wetlands International-Indonesia Progamme.

8. Milton R, Marhadi A (1985) The Bird Life of the Nature Reserve Pulau Dua. Ornithological Soc. 2: 32-41.

9. Ashton EC, Hogarth PJ, Ormond R (1999) Breakdown of mangrove leaf litter in a managed mangrove forest in Peninsular Malaysia. Hydrobiologia. 413: 77-88.

10. Olson JS (1963) Energy storage and the balance of producer and decompocer in ecological systems. Ecology. 44: 322-331.

11. Garnier E, Cortez J, Bille SG, et al. (2004) Plant functional markers capture ecosystem properties during secondary succession. Ecology. 85: 2630-2637.

12. Sutoro ND, Setyowati M (2008) Hubungan sifat morfofisiologis tanaman dengan hasil kedelai. Penelitian Pertanian Tanaman Pangan. 27: 185 -190.

13. Choong, VC, Sesakumar A, Leh MUC et al. (1992) The fish and prawn communities of a Malaysian coastal mangrove system, with comparisons to adjacent mud flats and inshore waters, Estuarine. Coastal and Shelf Sci. 31: 703722.

14. Aerts R (1997) Climate, leaf litter chemistry and leaf litter decomposition and terestrial ecosystem; a triangular relationship. Oikos. 79 (3): 439-449.

15. Syamsurisal (2011) Studi beberapa indeks komunitas makrozoobentos di hutan mangrove kelurahan Coppo Kabupaten Barru. Skripsi. Hasanuddin University, Fakultas Perikanan dan Ilmu Kelautan.

16. Nontji A (1993) Laut Nusantara. Bandung Indonesia: Reftka Aditama Press. 367pp.

17. Chapman VJ (1976) Mangrove vegetation. Vadus: J. Cramer.

18. Yunasfi (2006) Dekomposisi serasah daun Avicennia marina oleh bakteri dan fungi pada berbagai tingkat salinitas. Disertasi. Bogor Agricultural University, Departemen Ilmu Kelautan.

19. Dix NJ, Webster A (1995) Fungal Ecology. London: Chapman and Hall.

20. Umar RM (2006) Biodiversitas makrobentos (kelas Bivalvial, Echinoidea dan Asterdidea) pada perairan padang lamun di perairan Bone Batang Kepulauan Spermonde. BIOMA. 1 (1): 1-11.

21. Tahir A (2012) Ekotoksikologi dalam Perspektif Kese- 
hatan Ekosistem Laut. Bandung: Karya Putra Darmawati.

22. Lee CD, Wang SE, Kuo CL (1978) Benthic macroinvertebrate and fish as biological indicator of water quality. In proceedings of the International Conference on Water Pollution Control In developing Countries: 21-25 February 1978; Bangkok Thailand. Duoano EAR, Lohani BN, Thanh NC (Eds): Asian Institute of Technology Bangkok Thailand. 141-148.

23. Ulqodry TZ (2008) Produktivitas serasah mangrove dan potensi kontribusi unsur hara di perairan mangrove Tanjung Api-Api Sumatera Selatan. Tesis. Bogor Agricultural University, Departemen Ilmu Kelautan.

24. Steinke TD, Naidoo G, Charles LM (1983) Degradation of mangrove leaf litter and stein tissues in situ in Megeni Estuary South Africa, in Teas HJ [ed]. Task For Vegetation Sci.8: 141-149.

25. Wijiyono (2009) Keanekaragaman bakteri serasah daun Avicennia marina yang mengalami proses dekomposisisi pada berbegai tingkat salinitas di Teluk Tapian Nauli. Tesis. Sumatera Utara University, Departemen Biology.

26. Liaw MK (1969) Chemical and biological Studies of Fish Pond and Resevoir in Taiwan. Chinese American Joint Comission on Rural. Reconstruction Fish. 7:1-43.

27. Dalzell HW, Biddlestone AJ, Gray KR et al. (1987) Soil management: compost production and use in tropical and subtropical environments. Rome Italy: FAO Soils Bull. 